\title{
Myelomeningocele as newborn complication of lupus patient. A singular case.
}

\author{
TMSc. Dr. Urbano Solis Cartas ${ }^{1^{*}}$, MSc. Dr. Guillermo Gualpa Jaramillo ${ }^{2}$, Dr.C. Pablo \\ Djabayan Djibeyan ${ }^{3}$, MSc. Lilia del Carmen Villavicencio Narváez ${ }^{4}$ \\ ${ }^{*}$ Specialist of 1st Degree in Rheumatology and General Medicine. Researcher. Master in Satisfactory \\ Longevity. Researcher UNACH. National University of Chimborazo. Riobamba. Chimborazo. \\ ${ }^{2}$ Specialist in Neurosurgery. Master in Occupational Health and Safety. Teacher UNACH. National \\ University of Chimborazo. Riobamba. Chimborazo. Ecuador.
}

${ }^{3} \mathrm{PhD}$ in Pharmacy and Biomedical Sciences. Researcher UNACH. National University of Chimborazo. Riobamba. Chimborazo. Ecuador.

${ }^{4}$ Doctor in promotion and education for health. Master's degree in health management for local development. Researcher UNACH. National University of Chimborazo. Riobamba. Chimborazo. Ecuador.

Received: January 31, 2017; Accepted:April 19, 2017; Published: June 8, 2017

*Corresponding author: Specialist of 1st Degree in Rheumatology and General Medicine. Researcher. Master in Satisfactory Longevity. Researcher UNACH. National University of Chimborazo. Riobamba. Chimborazo. Ecuador. Phone: 0969467803; E-mail: umsmwork74@gmail.com

\begin{abstract}
Introduction: pregnancy is considered a risk in patients with rheumatic diseases. The relationship between pregnancy and rheumatic diseases is colored by exacerbation or remission of the disease and possible effects of pregnancy and your final product. Disorders of neural tube development are the second largest group of congenital malformations, with the myelomeningocele is one of the most common malformations.
\end{abstract}

Case presentation: the case of a newborn with myelomeningocele, the son of a female patient of 27 years diagnosed with systemic lupus erythematosus 4 years of evolution is presented.

Conclusions: congenital malformations in patients with rheumatic diseases can respond to various causes. Myelomeningocele complicates the evolution of the newborn with potential neurologic.

Key words: Pregnancy; Lupus Erythematosus, Systemic; Meningomyelocele; Infant, Newborn.

\section{Introduction}

Rheumatic Diseases (RD) are a group of about 250 diseases that are characterized by fundamentally affecting the osteomioarticular system. Clinically the presence of pain, inflation, stiffness and deformity are reported as largely responsible for the functional disability and the decrease in the perception of HealthRelated Quality of Life (HRQL) that produce these diseases [1].

The RD affects about $43 \%$ of the world population, with a predominance of female involvement. A peak incidence is described at age 50 but there are pathologies, such as systemic lupus erythematosus (LES), which appear at earlier ages [2, 3].

By affecting LES in young women of childbearing age, it is relatively common for many of them to decide to conceive a pregnancy. For some time, despite the fact that pregnancy is still considered a risk situation for patients with RD and mainly LES, the follow-up schemes of these patients have been improved, obtaining very satisfactory results $[3,4]$.

It is described an ambiguous relationship between LES and pregnancy, describing that the latter can exacerbate the activity of the disease and that LES can cause several havoc on gestation and its final product. Possible causes of involvement of LES in pregnancy include the disease's own activity and the use of certain medications that can lead to a threat of abortion and preterm deliveries, to the appearance of congenital malformation $[5,6]$.

Defects of the neural tube closure are the second largest group of congenital malformations. Myelomeningocele (MMC) is described as one of the most frequent malformations in this group, with an incidence ranging from 1-17 cases per 1000 live births in underdeveloped countries, which vary from one population to another and also in function Geographical factors, time and certain maternal demographic characteristics [7].

The etiology of MMC is multifactorial, in which both genetic and environmental factors interact. Consequently, several genes have been postulated as candidates to be responsible, 
which are related to metabolic pathways such as the transport and metabolism of vitamin B12, folates and methylation processes [8]. It is characterized by an early malformation in the embryonic development of the spinal cord, spinal cord, roots and meninges [9]. It is considered a complex malformation, consisting of a herniated sac containing the spinal cord, meninges or spinal roots and cerebrospinal fluid. It is accompanied by an incomplete fusion of the vertebral arches. They are usually covered by skin or a thin membrane that breaks easily, and can be located anywhere along the spine [10].

Some risk factors for the onset of MMC are described, such as the previous history of family members with this disorder, pre gestational and gestational diabetes mellitus, presence of autoimmune diseases, low intake of folic acid and maternal use of some drugs such as Anticonvulsants (valproic acid and carbamazepine) and some immunosuppressant's [7].

MMC can cause significant deterioration of skeletal muscle due to progressive deformities of bone and joints, whether due to pathological fractures and deterioration and / or muscle weakness. The presence of bone demineralization in the bones of the pelvic extremity is frequent due to muscle weakness or inactivity and its consequences, which translates into the need for immediate surgical treatment. Clinically they are children with paraplegia, loss of lower body sensation and sphincter incontinence. Within its clinical manifestations it is to emphasize the presence of dysfunction of different organs such as the bladder and the instetino which causes serious adaptive difficulties. Hydrocephalus and / or Arnold-Chiari malformation may be associated, among other alterations [8-10].

This is why, considering that autoimmune diseases and the use of immunosuppressive drugs are reported as risk factors for the onset of MMC, its high incidence and the scarcity of reports that show the occurrence of this congenital malformation in patients with RE, Presents this case of a newborn with MMC, son of a lupic patient of 4 years of evolution.

Treatment initially consists of closing the defect of the neural tube and the treatment of hydrocephalus if present, and then emphasizing the treatment of the possible complications already mentioned [9].

\section{Case Presentation}

Newborn of 4 days, son of a 27 year old patient diagnosed for 4 years of SLE. The child is born at 38.3 weeks of gestation with a weight of $2787 \mathrm{gr}$, a size of $52 \mathrm{~cm}$, a cephalic circumference of $39 \mathrm{~cm}$ and a APGAR of $8 / 10$ a minute and five minutes after birth.

On physical examination, thepresence of a corresponding lumbar region (Figure 1) with a myelomeningocele, as well as the presence of a bilateral equine varus foot (Figure 2)

Significant data from the prenatal period include a history of treatment with azathioprine (50 mg daily) and prednisone in doses ranging from 5 to $20 \mathrm{mg}$ daily. In addition, from the 18 weeks of gestation, high glycemia levels were

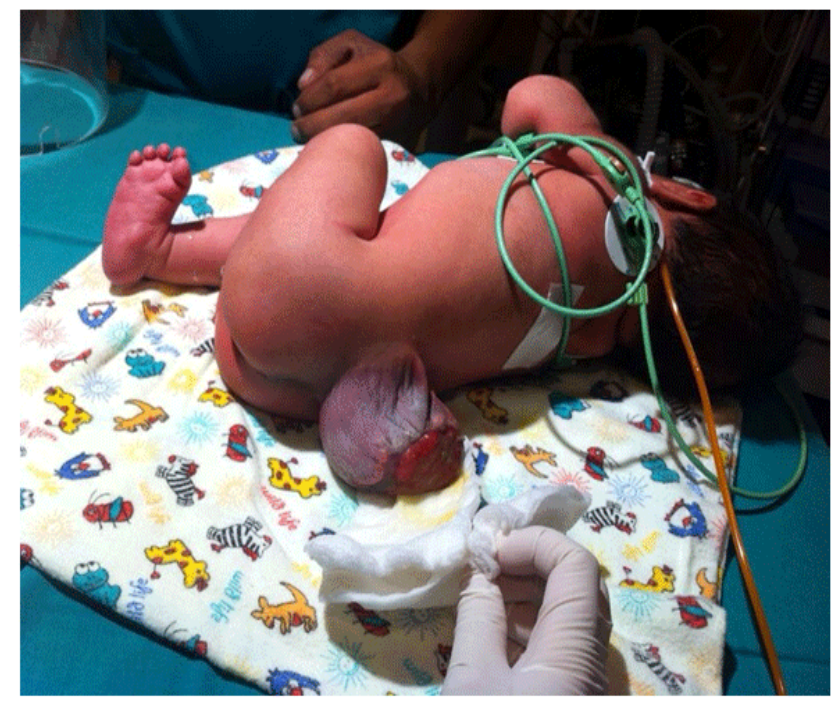

Figure 1: Bag showing meninges content and terminal neural plate exposure in the lumbar region. Bilateral equine varus foot.

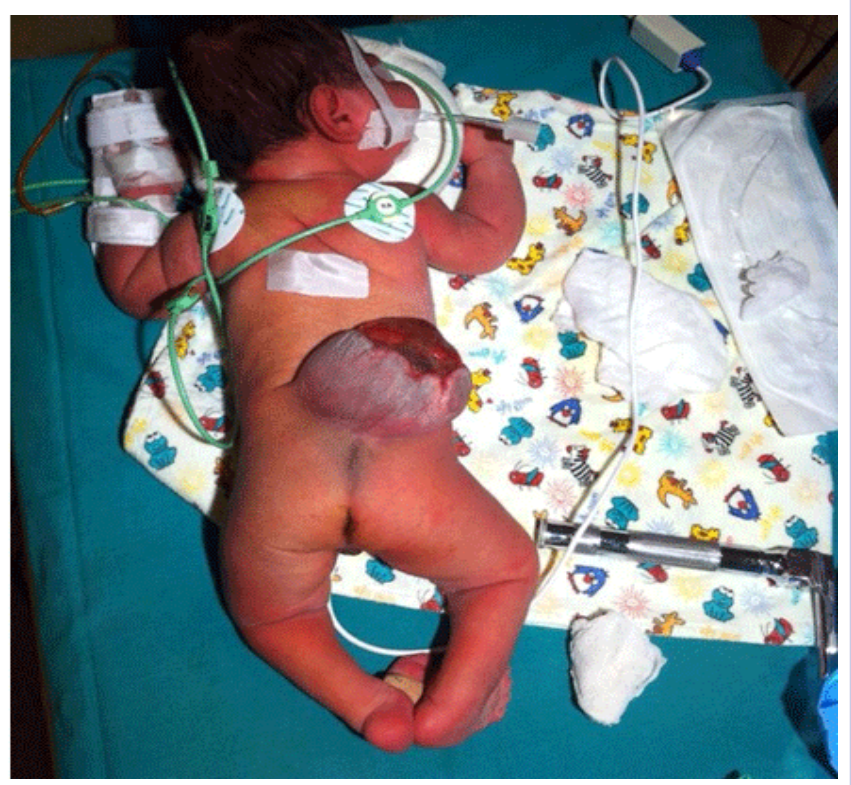

Figure 2: Equine right varus foot.

presented, which was then consulted with obstetricians who underwent dietary restrictions. Another important element in this case was the irregularity of the administration of vitamin supplements to the patient.

During gestation, only 3 controls with a rheumatology specialization and 4 controls with obstetrics were used, and an obstetric echo was performed in one control.

The newborn was surgically operated and, since to date, has a favorable evolution. 


\section{Discussion}

The MMC is a malformation of the neural tube that, despite having a relatively low incidence, causes great affectation of the quality of life of the patient.

In this case it was presented in a male patient, it is reported that there is no predominance by sex or race for the appearance of the malformation, although some authors such as González A, et al7 describe a predominance of affectation in the female sex; However, what does exist is a predominance of the area of appearance of the same, being reported that is more frequent in the lumbar area with respect to other regions of the spine, as occurred in this case [7, 8].

Authors like Calderón Porras, SE10 report that in $60 \%$ of the patients the affectation is located in the low lumbar region (L3-L5). At this level, the force is present in hip and knee flexors, hip adductors and large quadriceps; While the force on vast lateral, abductor hip and ankle dorsiflexors is variable. There is no activity in plantar flexors. The feet may have deformity in the equine varus at birth, and it is important to begin stabilization soon with bandages or splints to maintain good stabilization. The knees may appear flexed or hyperextended and there may be instability and dislocation of the hips, which requires immediate conservative treatment [10].

When the involvement is at the level of the high lumbar group (T8-L2), there is a compromise of the strength of upper limbs, trunk, abdomen and total lower limb involvement, this location occurs in about $30 \%$ of MMC cases. 10 The remaining 10 $\%$ of the location of the MMC corresponds to the sacrum group, in this group the children have a good prognosis, their muscular activity is better and therefore, the development of the motor and functional potential is good with respect to obtaining an Independent gear [10].

Regarding the possible risk factors for the appearance of the malformation, it should be noted that this patient is an autoimmune disease, with treatment with immunosuppressive drugs (azathioprine and the immunosuppressive effect of steroids). In addition, high levels of glycemia during pregnancy and inadequate administration of vitamin supplements during gestation, which significantly decrease the contribution of folic acid and B-complex vitamins are recorded. All these elements have been reported as possible risk factors for pregnancy. Appearance of MMC [7].

In the case of immunological diseases, it is known that these can affect during pregnancy, in the case of LES, the possible occurrence of, among others, threat of abortion, preterm deliveries, newborns with low birth weight, and presentation abnormalities of the placenta, placental hemorrhages, retarded intrauterine growth (IUGR), macrophages, hydrocephalus and the occurrence of congenital malformations such as MMC. Adequate family planning, which leads to pregnancy with good control of the underlying disease; Coupled with adequate obstetric followup with active malformations research could minimize the occurrence of this disease $[5,11-13]$.
In Ecuador, despite the great efforts made to achieve improvement rates in relation to the maternal and child program, there is still a long way to go in terms of family planning as well as obstetrical control and by other specialists in patients with nonchronic diseases. Communicable diseases (CNCDs).

Another element that is described as a risk factor and that is closely related to autoimmune diseases is the use of drugs with immunosuppressive action. This patient, during her pregnancy, is being treated with azathioprine and relatively low doses of steroids. Both drugs have been approved for the treatment of SLE during pregnancy and have been classified as safe despite there being always a minimal risk of malformations. In the case of azathioprine a possible explanation could be given by the competition with the enzyme xanthine oxidase which would hamper the processes of degradation and assimilation of uric acid, folic acid and B-complex vitamins [14-16].

High blood glucose levels during pregnancy, even without developing gestational diabetes, significantly influence the mechanisms of absorption and utilization of folic acid and B-complex vitamins; Elements that are essential for the correct closure of the neural tube. When there are difficulties in its physiological mechanisms may appear neural tube closure defects, with appearance of spina bifida and presence of MMC [15, 16]. In the case reported, high levels of glycemia are described during gestation, being evaluated by a specialist who, at the time, considered it appropriate to make only dietary recommendations.

The administration of vitamin supplements rich in folic acid and B-complex vitamins, especially B12, is one of the measures that have been taken to reduce the appearance of malformations such as MMC $[10,15,16]$. Countries with higher rates of development The United States of America, Ireland, the United Kingdom, China, Hungary, Chile and Mexico, have managed to reduce the incidence of MMC based on the administration of these supplements during pregnancy, and even nowadays its administration is suggested for a Less than 6 months before conception of pregnancy. The administration of multivitamin supplements is more relevant in patients with NCDs who wish to have a healthy pregnancy $[15,16]$.

The patient describes an irregular and inadequate administration of supplements during pregnancy, and null in the preconceptional stage. In addition, he reports insufficient obstetric and rheumatologic follow-up for his underlying disease. In Ecuador, it is still quite common for lower-class families to ignore the importance of family planning, control of NCDs, adequate obstetric follow-up, and the nutritional and therapeutic value added by vitamin supplements $[13,17]$.

\section{Conclusions}

The MMC is a congenital malformation that diminishes the perception of health related quality of life for both patients and their families. Maintaining an adequate control of ECNT before and during pregnancy, proper obstetric follow-up during pregnancy and the administration of vitamin supplements rich in folic acid and B-complex vitamins are essential elements in order 
to reduce the incidence of onset of MMC

\section{Declaration}

In the execution of this report there are no conflicts of interest, neither budgetary support nor ethical conflicts with the patients and authors of this report.

\section{References}

1. Solis-Cartas U, Prada-Hernández D, Molinero-Rodríguez C, de-ArmasHernandez A, García-González V, et al. Rasgos demográficos en la osteoartritis de rodilla. Rev Cubana de Reumatol. 2014;17(1):32-39.

2. Prada-Hernández D, Hernández-Torres C, Gómez-Morejón J, GilArmenteros R, Reyes-Pineda Y, et al. Evaluación de la calidad de vida relacionada con la salud en pacientes con artritis reumatoide en el Centro de Reumatología. Rev Cubana de Reumatol. 2014;17(1):48-60.

3. Solis-Cartas U, Garcia-Gonzalez V, de-Armas-Hernandez A. Rasgos demográficos en la osteoartritis de manos. Rev Cubana de Reumatol. 2014;16(3):268-275.

4. Gil-Armenteros R, Solis-Cartas U, Milera-Rodríguez J, De-ArmasHernandez A. Mielitis transversa como debut de un lupus eritematoso sistémico. Rev Cubana de Reumatol. 2013;15(3):209-213.

5. Guibert Toledano ZM, Reyes Llerena GA, Rigñack Ramírez L, Cruz García Y, Acosta Lapera D, Salgado Galloso SB. Embarazo y puerperio en el lupus eritematoso sistémico. Actualización. Rev Cubana de Reumatol. 2013;15(2):71-75.

6. Torres Lima AM, Hernández Cuéllar MV, Rodríguez Torres AY. Sistema Inmune y embarazo: características generales en mujeres sanas y en pacientes con enfermedades reumáticas. Rev Cubana de Reumatol. 2013;15(2):76-82.

7. González A, Nazar C, Bastidas J, Zamora M, Mellado P, Lacassie H. Anestesia neuroaxial en trabajo de parto y cesárea en pacientes con antecedentes de mielomeningocele operado. Rev. chil. obstet. ginecol. 2014;79(6):531-36.

8. Pardo R, Suazo J, Castillo S, Vargas M, Zalavari A, et al. Estudio de asociación de base familiar entre polimorfismos de MTHFR y mielomeningocele en Chile. Rev. méd. Chile. 2014;142(5):587-92.
9. Rotter K, Solís F, González M. Costos de atención en pacientes con mielomeningocele en los Institutos de Rehabilitación Infantil Teletón. Rev. chil. pediatr. 2007;78(1):35-42.

10. Calderón-Porras SE, Mancilla-Ramírez A, Rolón-Lacarriere OG. Hidrocinesiterapia y Halliwick en niños con mielomeningocele. Rev Mex Neuroci. 2012;13(2):86-92.

11. Reyes Pineda Y, Martínez Larrarte JP. Lupus eritematoso sistémico y embarazo. Planteamiento bioético. Rev Cubana de Reumatol. 2005;7(7-8).

12. Solis-Cartas U, Amador-García D, Crespo-Somoza I, Pérez-Castillo E. Síndrome de Guillain Barré como forma de debut en el lupus eritematoso sistémico. Rev Cubana de Reumatol. 2015;17(2 Suppl. 1):220-223.

13. Martínez Larrarte JP. La responsabilidad del conocimiento durante el transcurso del embarazo en las enfermedades reumáticas. Revista Cubana de Reumatología. 2013;15(2):57-59.

14.López Mantecón AM, Reyes Pineda Y, Hernández Cuellar MI, Prada Hernández DM, Molinero Rodríguez C. Artritis reumatoide y embarazo. Rev Cubana de Reumatol. 2013;15(2):83-90.

15. Cortés F, Mellado C, Pardo RA, Villarroel LA, Hertrampf E. Wheat four fortifications with folic acid: Changes in neural tube defects rates in Chile. Am J Med Genet A. 2012;158A:1885-1890. doi:10.1002/ ajmg.a.35430.

16. Etheredge AJ, Finnell RH, Carmichael SL, Lammer EJ, Zhu H, et al. Maternal and infant gene-folate interactions and the risk of neural tube defects. Am J Med Genet A. 2012;158A(10):2439-2446. doi: 10.1002/ajmg.a.35552.

17. Prada Hernández DM, Oliva Rodríguez J, Molinero Rodríguez C, Gómez Morejón JA, Hernández Cuellar MV, et al. Utilidad del Consejo preconcepcional en enfermedades reumáticas autoinmunes. Rev Cubana de Reumatol. 2003;15(2):63-70. 